\title{
VERTICAL HYDROCHEMICAL PROFILES IN THE UNSATURATED ZONE OF LOUGA (SENEGAL) AQUIFER CONTROLLED BY GEOCHEMICAL PROCESSES
}

\author{
Serigne, F. and Seynabou, C. F. \\ Geology Department, Faculty of Sciences, University Cheikh Anta Diop, \\ Dakar-Fann, SENEGAL
}

\begin{abstract}
Solutions chemistry of the rainwater and the unsaturated zone interstitial water of Louga (Northern Senegal) local aquifer provide valuable information related to water-rock interaction occurring during natural recharge. Non reactive chloride ion and rainwater ion/ chloride molar ratios are used as a baseline against which sequential uptake and release of solutes from/to the unsaturated zone solution may be studied. Cation exchange capacity (CEC) and exchangeable cation (EC) experiments, together with chemical analysis of the interstitial water carried out through the entire unsaturated zone profile have revealed that base exchange reactions and dissolution of silicate minerals are the dominant processes controlling the water chemistry. In the uppermost $7 \mathrm{~m}$ of the profile, silicate weathering dominates, this process occurs at low $\mathrm{pH}$ (3.5 -4). Major cations and silicium are released to the interstitial water above the calibrated rainwater reference. Below this depth, exchange reactions dominate, they are accompanied by a gradual increase in $\mathrm{pH}$ (up to 5). However, ion selectivity reaction seems to control the concentration of the cations. Preference of bivalent cations $\left(\mathrm{Ca}^{2+}, \mathrm{Mg}^{2+}\right)$ over monovalent cations $(\mathrm{K}+, \mathrm{Na}+)$ by the clay minerals may explain the chemistry of both the unsaturated zone solutions and at the immediate water table.
\end{abstract}

\section{INTRODUCTION}

Understanding groundwater chemistry requires knowledge of the hydrology and hydrochemistry evolution as water travels through various pathways in a aquifer reservoir. Basic geochemical reactions, such as water-rock interactions and silicate minerals dissolution, change solute composition of the aquifer system. On one hand, we need to understand these basic processes controlling the water quality by laboratory experiments, and on the other hand, we need to understand the evolution of the chemical change due to these processes in a real world pathways of the aquifer system.

The Louga aquifer, which is of concern in this study, is located North of Senegal (Fig.1) and belongs to the Senegal North coast aquifer system. It represents an important reserve for rural and urban water supply. The local groundwater resource has been subject to initial studies to evaluate natural recharge (Gaye and Edmunds, 1996 ; Edmunds and Gaye, 1994 ; Edmunds et al, 1992 and Cook et al, 1992) and plans for the development and exploitation of the groundwater reserves (Faye, 1995 ; Faye et al, $1997 \&$ 1998).

This paper sets out to identify and explain the main geochemical processes controlling the local groundwater chemistry. Using experiments of exchange reactions in the unsaturated zone samples obtained from one profile (L18) and chemical analysis of the interstitial water from the same profile, it is then possible to interpret chemical changes of the infiltrating water through the unsaturated zone media and water chemistry at the immediate water table. 


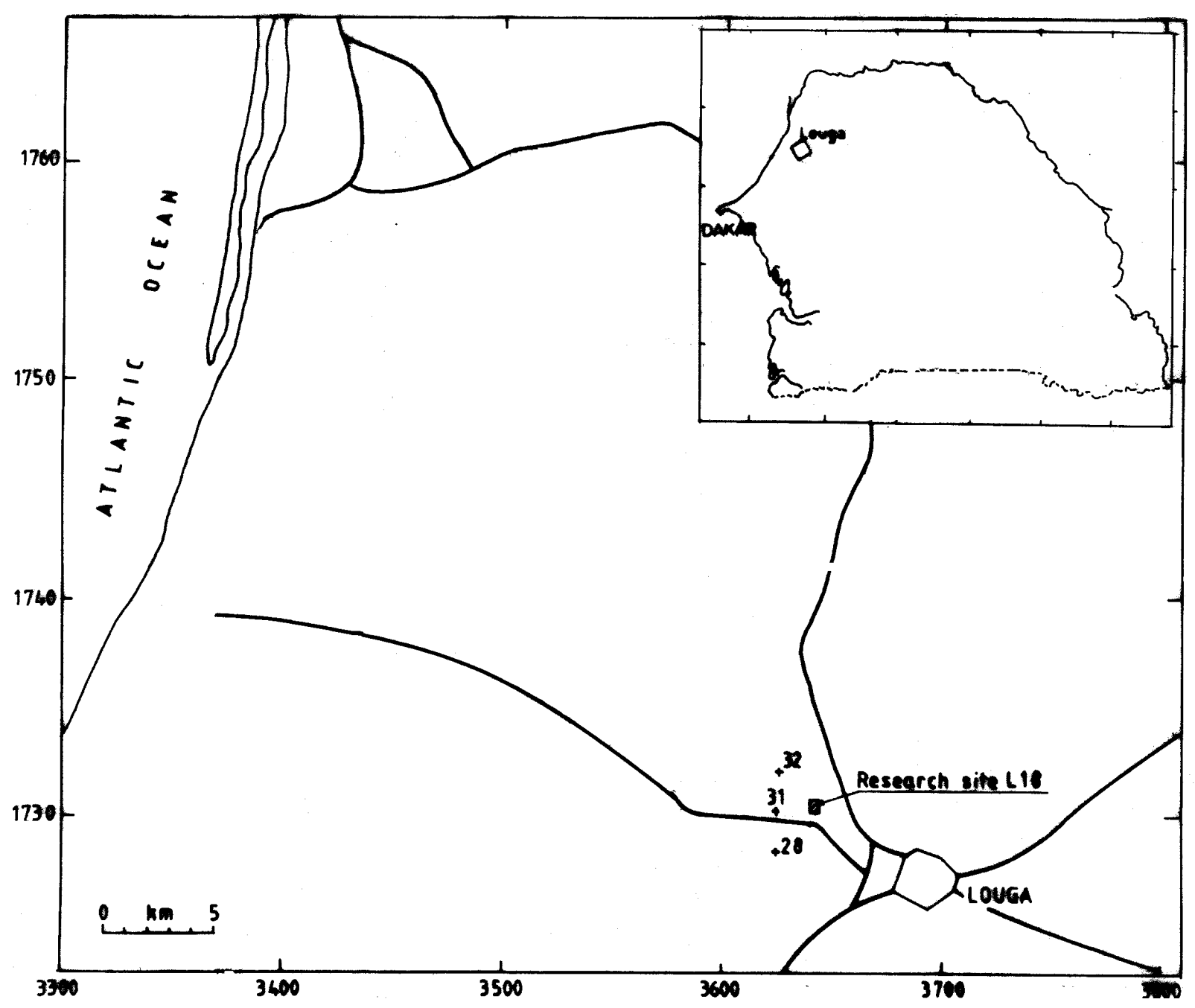

Figure 1. Location of the study area

\section{Geology}

The unconfined quaternary sand aquifer is located in the north west of the Senegal sedimentary basin (Fig.1). It extends about 2,300 $\mathrm{km}^{2}$ and overlies an Eocene marl.

The aquifer reservoir is composed of sands, clayey sands and sandy clays, and most of the materials are of continental origin, were deposited during the quaternary (<0.3 Ma). Locally, pure sand deposits are interbedded by clay layers and sandy clays. This later structure is responsible for the change in hydraulic conductivity $\left(2.8 \times 10^{-5}\right.$ to $\left.8.5 \times 10^{-4} \mathrm{~m} / \mathrm{s}\right)$ (Faye et al, 1998). The sands are composed of 90-95\% quartz and some feldspar, 5-10\% of clay mineral. Analysis of the clay fraction by X Ray Diffractometer (XRD) revealed the presence of illite, kaolinite and trace quantities of montmorillonite (Faye, 1991)

The reservoir thickness varies from 40 to $160 \mathrm{~m}$. the maximum reservoir thickness is located near Louga. Towards the ocean, the thickness decreases due to an uplift of the marly substratum and the reservoir becomes more clay in content. 
Vertical Hydrochemical Profiles in the Unsaturated Zone of Louga (Senegal) Aquifer Controlled by Geochemical Processes

\section{Hydrogeology}

The quaternary sand aquifer is a one layer unconfined system that overlies an impervious marl. The groundwater flows from a potentiometric dome $(35 \mathrm{~m})$ located South East towards the north (in Louga area), the west and into the ocean and the limestone aquifer in the East. Under natural conditions, the aquifer system recharges by rainfall infiltration mainly at the potentiometric dome zone. The natural discharge occurs by lateral flow towards the ocean and toward the limestone aquifer. Natural discharge by vertical upward evapotranspiration occurs also in the coastal zone where groundwater level is at or close to the ground surface.

Early studies on estimate of groundwater recharge and paleorecharge using non reactive chloride ion were widely used in the Louga region (Gaye and Edmunds, 1996 ; Edmunds and Gaye, 1994 ; Edmunds et al, 1992 and Cook et al, 1992). Concern over the hydrogeological impacts resulting from increasing abstraction of the groundwater resource was also investigated using a regional numerical model (Faye, 1995 ; Faye et al, 1997 et 1998). Results of these different studies indicated a very low replenishment of the groundwater system, both calculated and simulated recharges are below $17 \mathrm{~mm} / \mathrm{yr}$. In the Louga region, recharge rate may diminish to values below zero indicating a discharge by evaporation. The low groundwater replenishment is the result of the recent climatic change (drought since 1969), which in the study region represents a decline of $36 \%$ in rainfall compared to the long-term average of $356 \mathrm{~mm} / \mathrm{yr}$. This low recharge rates together with the increased abstraction lower continuously the water table by $2 \mathrm{~m}$ per decade. This decline is of concern since traditional wells that supply the rural water needs penetrate 1 to $2 \mathrm{~m}$ below the water table.

\section{METHODOFSTUDY}

The study considered a single profile L18 (Fig. 1) which represents the entire unsaturated zone of the Quaternary sand aquifer near Louga. The profile has been sampled at intervals of $25 \mathrm{~cm}$ from ground level to $10 \mathrm{~m}$ depth, and increasing to $50 \mathrm{~cm}$ intervals from $10 \mathrm{~m}$ to the water table at $35.5 \mathrm{~m}$ depth using hand auger. Samples were bulked, homogenised and collected in $1,000 \mathrm{ml}$ sealed glass containers.

Sand moisture were determined using gravimetric method by drying $100 \mathrm{mg}$ of sample at $110^{\circ} \mathrm{C}$ for 12 hours. Interstitial water from the samples was extracted by centrifugation at 13,000 rpm using immiscible liquid displacement. In samples where moisture contents were below $3 \%$, a surfactant of $10 \mu \mathrm{l} / \mathrm{l}$ was added to the heavy liquid ARKLONE to increase yield (Kinniburg and Miles, 1983). Typically, $5 \mathrm{ml}$ of the interstitial water were obtained (representing 30 to $50 \mathrm{ml}$ of the total moisture) and were either directly used or diluted at a ratio $1: 1$ with highly pure water.

Three types of analysis were performed :

- Analysis of the liquid phase : the chemical analysis was carried out in rainwater, interstitial water and groundwater samples for ionic concentrations of the major constituents. Chloride content were determined using an automated colorimetric method, and $\mathrm{Na}^{+}, \mathrm{K}^{+}, \mathrm{Ca}^{2+}, \mathrm{Mg}^{2+}$ and $\mathrm{Si}$ using an Induction Coupled Plasma (ICP-EOS).

- Analysis of the solid phase : the mineralogy of the sand fraction were analysed using an Scanning Electrode Microprobe (SEM), and the mineralogy of the clay fraction were analysed using an XRD (X Ray Diffractometer) (Faye, 1991).

- Analysis of exchange reactions : Cation exchange capacity (CEC) and exchangeable cations (EC) experiments were carried in the soil samples obtained in the entire profile.

- For the CEC experiment, $2 \mathrm{~g}$ of samples were leached with $0.1 \mathrm{M} \mathrm{BaCl}$ for 2 hours, then equilibrated 3 times with $0.002 \mathrm{M} \mathrm{BaCl}$. The mixture was filtered, then 10 $\mathrm{ml}$ of $\mathrm{MgSO}_{4}$ were added to the sand and shaken for 1 hour. After determining the electrolytic of a $\mathrm{BaSO}_{4}$ solution $0.0015 \mathrm{M}$. the mixture sand/ $\mathrm{MgSO}_{4}$ was equilibrated to this conductivity by adding either water or $\mathrm{BaSO}_{4}$ (Gillman, 1979). The CEC is obtained by the formula $\mathrm{CEC}=50 \mathrm{x}(\mathrm{CxV})$ where $\mathrm{C}$ is concentration of $\mathrm{Mg}$ in meq/100 $\mathrm{g}$ of sample and $\mathrm{V}$ the final volume of the filtrate. $\mathrm{Mg}$ were analysed by ICP-EOS

- For the EC experiment, $20 \mathrm{ml}$ of $1 \mathrm{M}$ Ammonium Acetate was added to $5 \mathrm{~g}$ a sand sample, the mixture is shaken and allowed to rest overnight. After filtering, $25 \mathrm{ml}$ of $1 \mathrm{M}$ ammonium acetate was added 9 times by removing the liquid before each addition. The finale filtrate was analysed by AAS for the determination of the cations. The exchangeable cations are determined by the formula $\mathrm{EC}=\mathrm{A} \times 50$ $\mathrm{mg} / \mathrm{kg}$ where A represents the concentration of the cations $\left(\mathrm{Na}^{+}, \mathrm{K}^{+}, \mathrm{Ca}^{2+}\right.$ or $\left.\mathrm{Mg}^{2+}\right)$ analysed by ICPEOS. 


\section{RESULTS}

\section{- Rainwater chemistry}

Table 1 shows the 1988 weighted mean average of the rainwater chemistry form 14 rainy episodes in Louga region (Edmunds, 1990).

Table 1: Rainwater chemistry in $\mathrm{mmol} / \mathrm{l}$ and in molar ratios

\begin{tabular}{lrrr}
\hline \multicolumn{1}{c}{ Cations } & \multicolumn{1}{c}{ mmol/l } & \multicolumn{1}{c}{ Ion/chloride } & \multicolumn{1}{c}{ Ratio } \\
\hline $\mathrm{Na}^{+}$ & 0.03 & $\mathrm{Na} / \mathrm{Cl}$ & 0.99 \\
$\mathrm{~K}^{+}$ & 0.01 & $\mathrm{~K} / \mathrm{Cl}$ & 0.3 \\
$\mathrm{Ca}^{2}$ & 0.04 & $\mathrm{CA} / \mathrm{Cl}$ & 1.21 \\
$\mathrm{Mg}^{+}$ & 0.008 & $\mathrm{Mg} / \mathrm{Cl}$ & 0.24 \\
$\mathrm{Cl}^{-}$ & 0.033 & $\mathrm{Si} / \mathrm{Cl}$ & 0.3 \\
\hline
\end{tabular}

\section{- Hydrochemistry of the local groundwater}

Chemical composition (table 2) of the local groundwater has been studied using three traditional village wells located near to the L18 profile (Fig. 1). The water chemistry represented in a Piper diagram shows sodium chloride type facies (Fig. 2).

\section{- Vertical profile of the unsaturated zone water} chemistry

Vertical evolution of the chemistry of cations of the interstitial water during transit to the water table has been investigated using ion/chloride molar ratios. Chloride is considered here as inert to geochemical processes and its only source is from dry deposition and chloride content in rainwater.

Table 2: Chemical composition of Louga groundwater in mmol/l

\begin{tabular}{ccccccccccc}
\hline Well & Depth & $\mathbf{N a}^{+}$ & $\mathbf{K}^{+}$ & $\mathbf{C a}^{{ }^{2+}}$ & $\mathbf{M g}^{2+}$ & $\mathbf{C l}^{-}$ & $\mathbf{S O}_{4}{ }^{2-}$ & $\mathbf{H C O}_{\mathbf{3}}{ }^{-}$ & $\mathbf{N O}_{\mathbf{3}}{ }^{-}$ & $\mathbf{S i}$ \\
\hline 28 & 31.78 & 1.63 & 0.07 & 0.29 & 0.14 & 1.55 & 0.01 & 0.57 & 0.34 & 0.43 \\
31 & 37.05 & 1.79 & 0.16 & 0.61 & 0.77 & 2.17 & 0.016 & 1.15 & 0.89 & 0.44 \\
32 & 34.7 & 2.5 & 0.29 & 0.75 & 1 & 2.7 & 0.02 & 1.82 & 2.07 & 0.72 \\
\hline
\end{tabular}

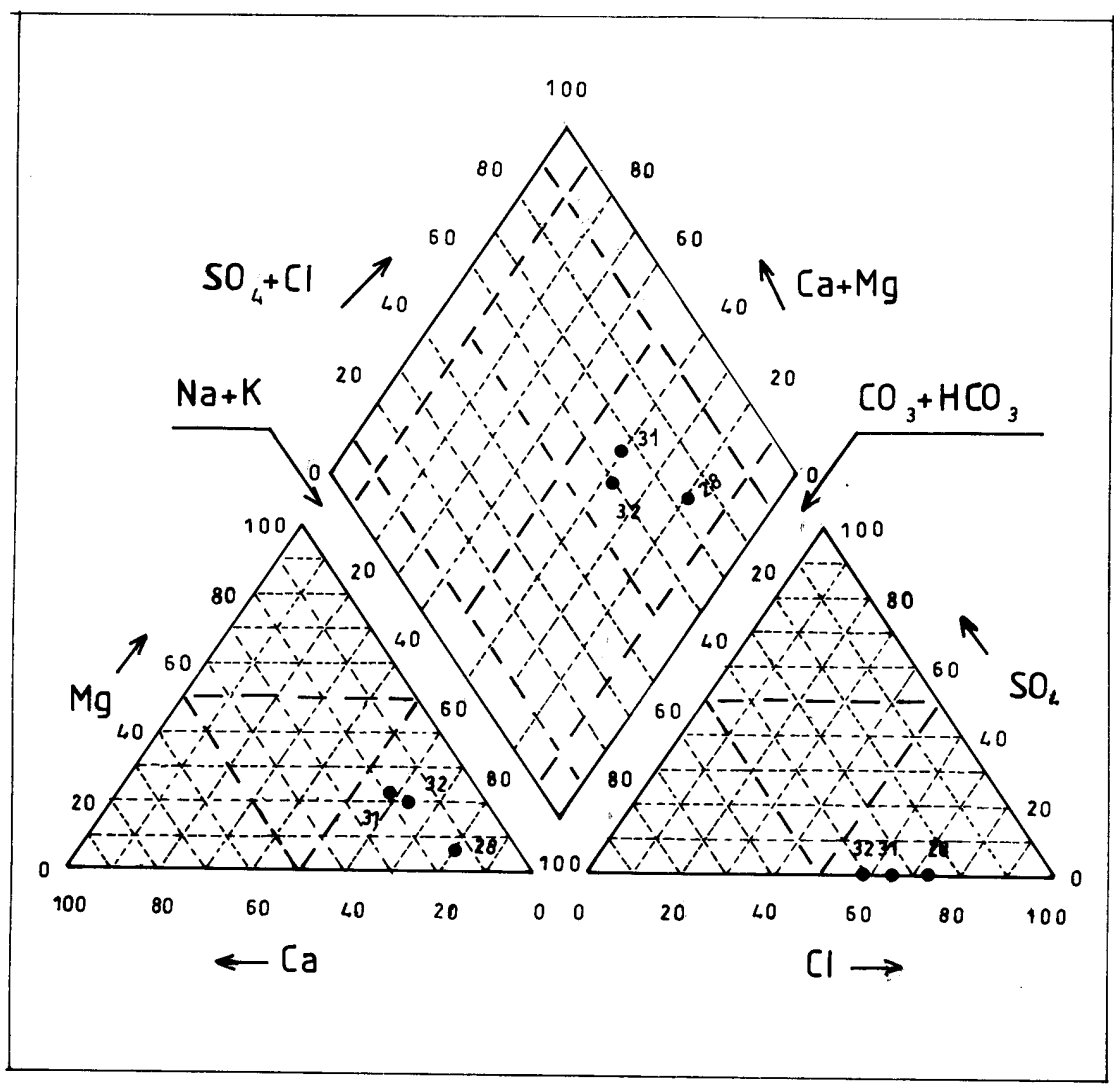

Figure 2: Piper diagram representing the local groundwater facies 
Vertical Hydrochemical Profiles in the Unsaturated Zone of Louga (Senegal) Aquifer

Controlled by Geochemical Processes

In figures $3 a, 3 b, 3 c$ and $3 c$, the following evolution can be seen:

- An increase of $\mathrm{Ca} / \mathrm{Cl}, \mathrm{Mg} / \mathrm{Cl}, \mathrm{K} / \mathrm{Cl}$ and $\mathrm{Na} / \mathrm{Cl}$ molar ratios up to depth of $6 \mathrm{~m}$;

- A decrease of $\mathrm{Ca} / \mathrm{Cl}$ and $\mathrm{K} / \mathrm{Cl}$ molar ratios from $6 \mathrm{~m}$ depth to the water table ;

- An important increase of $\mathrm{Na} / \mathrm{Cl}$ molar ratio from $12 \mathrm{~m}$ depth with a maximum at $20 \mathrm{~m}$;

- A varying trend of $\mathrm{Mg} / \mathrm{Cl}$ showing sharp peaks.
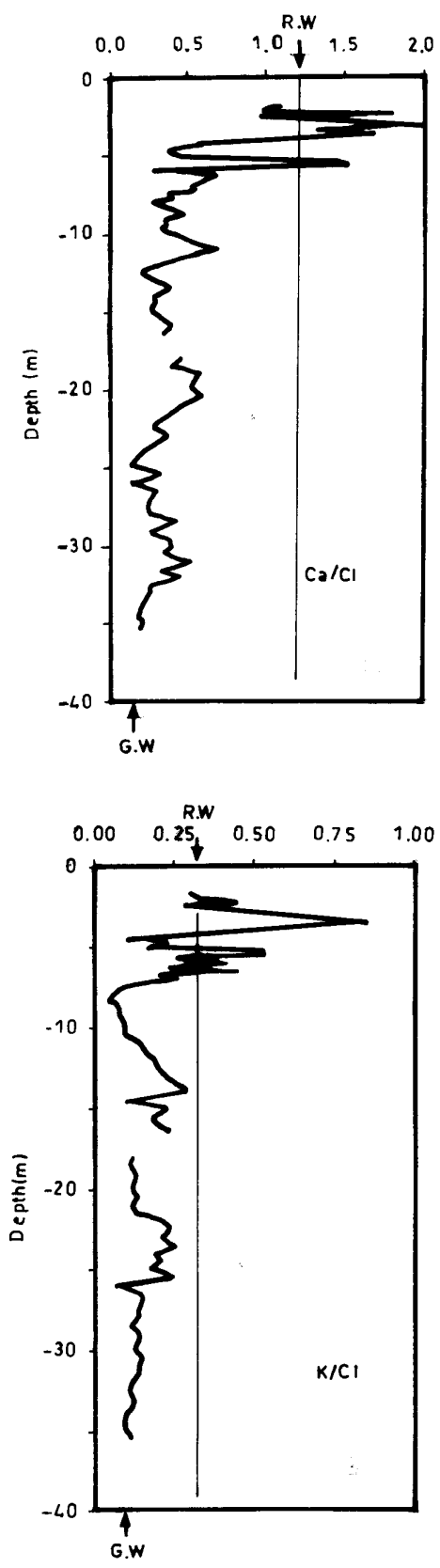

Calibration of the profile molar ratios to the reference local rainwater (entry signal) allowed for study of variations in terms of intake and uptake by geochemical processes. In fact, the shallow depth reservoir (from ground level down to $6 \mathrm{~m}$ ), represents an important release source of cations. Whereas, at deeper depth while $\mathrm{Ca}^{2+}$ and $\mathrm{K}^{+}$are taken up by the matrix, $\mathrm{Na}^{+}$is considerably released and $\mathrm{Mg}^{2+}$ ion is either released or taken up by the matrix.
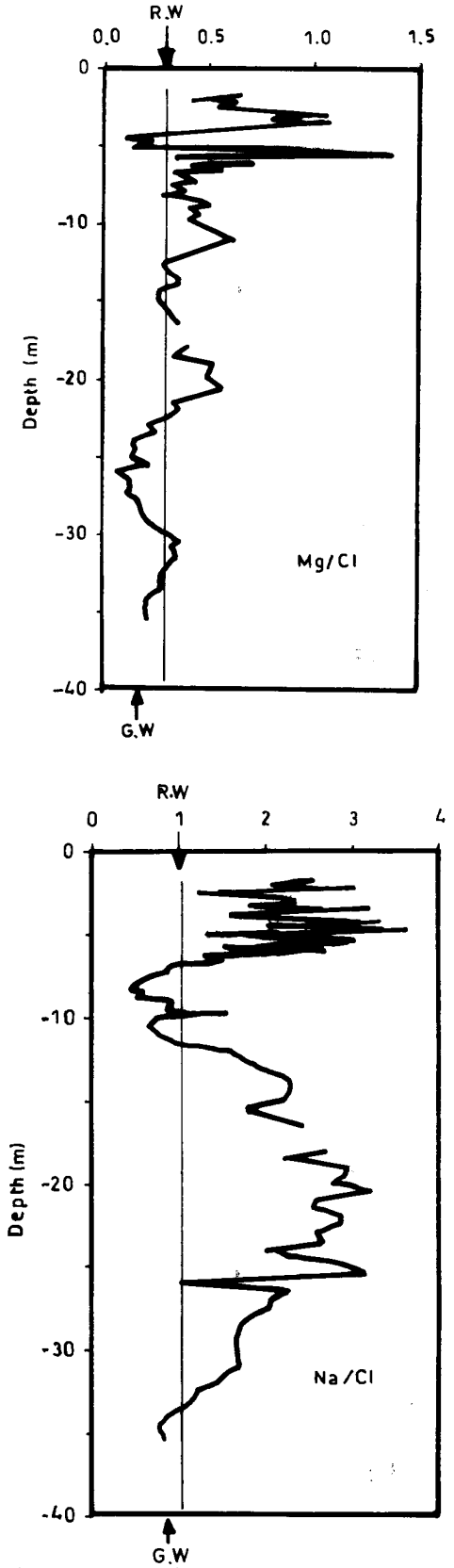

Figure 3. Vertical profile of the unsaturated zone water chemistry in molar ratio

(3a : $\mathrm{Ca} / \mathrm{Cl}, 3 \mathrm{~b}: \mathrm{Mg} / \mathrm{Cl}, 3 \mathrm{c}: \mathrm{K} / \mathrm{Cl}, 3 \mathrm{~d}: \mathrm{Na} / \mathrm{Cl}$ )

$(\mathbf{R} . \mathbf{W}=$ rainwater; $\mathbf{G} . \mathbf{W}=$ groundwater $)$ 


\section{- Exchange reactions}

Changes in chemical composition of the infiltrating water should reflect the mineralogy of the reservoir. Geochemical reactions responsible for these changes are rapid exchange reactions at the clay minerals surface, slow hydrolysis reactions, which weather primary minerals, and precipitation reactions.

Exchange reactions defined by CEC and EC experiments in the unsaturated zone samples have shown values of CEC around a mean value of $3 \mathrm{meq} / 100 \mathrm{~g}$ of soil (Fig. 4a). It decreases between 10 to $13 \mathrm{~m}$ depth, then increases from 13 to $31 \mathrm{~m}$ depth. The maximum value obtained is 3.8 meq/100 $\mathrm{g}$ of soil at $17 \mathrm{~m}$ depth. These values, obtained in low clay content (less than $10 \%$ ) sand samples, are relatively high compared to those measured in pure kaolinite (1 to $10 \mathrm{meq} / 100 \mathrm{~g}$ ) (Dolcaster et al, 1968). This indicates illite occurrence (which has a CEC value varying between 10 to $40 \mathrm{meq} / 100 \mathrm{~g}$ of pure illite) and perhaps montmorillonite ( 80 to $150 \mathrm{meq} / 100 \mathrm{~g}$ of pure montmorillonite) in the clay fraction which could increase the values observed in the profile samples. This observation is confirmed by the XRD analysis in clay which show abundant illite occurrence in the top of the profile, at mid depth and depth between 27 to $28 \mathrm{~m}$, whereas kaolinite is dominant in between. Montmorillonite is represented in trace quantities.

EC reactions in the same samples showed decreasing order of exchangeable cations : $\mathrm{Ca}^{2+}>\mathrm{Mg}^{2+}>\mathrm{Na}^{+}>\mathrm{K}^{+}$. However, two zones of different EC values can be separated (Fig. $4 b)$ :

A shallow zone between ground level to $10 \mathrm{~m}$ depth where values of EC are less than $2.5 \mathrm{mmol}$ per $\mathrm{kg}$ of soil ;

A deeper zone from $10 \mathrm{~m}$ depth to the water table where $\mathrm{EC}$ values for $\mathrm{Ca}^{2+}$ and $\mathrm{Mg}^{2+}$ are high with a maximum at $17.5 \mathrm{~m}$. This zone coincides with a rise in $\mathrm{pH}$ (Fig. 4c) which increases gradually to around 5 at $18 \mathrm{~m}$ depth. The low $\mathrm{pH}$ at around $30 \mathrm{~m}$ depth possibly marks a former high piezometric level.

\section{INTERPRETATION}

Combination of high CEC values and illite occurrence in the sand samples have shown that the later is the dominant clay exchanger, adsorbing more $\mathrm{Na}^{+}$than $\mathrm{K}^{+}$ compared to kaolinite. However in a monovalent-bivalent system, illite has shown its preference to bivalent cations:
$\mathrm{Ca}^{2+}+\mathrm{Na}_{2}$-illite $=2 \mathrm{Na}^{+}+\mathrm{Ca}$-illite
$\mathrm{Mg}^{2+}+\mathrm{Na}_{2}$-illite $=2 \mathrm{Na}^{+}+\mathrm{Mg}$-illite

Previous studies (Udo, 1978 ; Jensen, 1973) on equilibrium of exchangeable cation reactions in the systems K-Ca, $\mathrm{Na}-\mathrm{K}$ and $\mathrm{Na}-\mathrm{Ca}$ with kaolinite, have shown a high selectivity of $\mathrm{K}^{+}$over $\mathrm{Ca}^{2+}$ which is independent of the ionic strength of the solution.

Negative variation of Gibbs free energy found in the following reversible exchange (Goulding and Talibudeen, 1980) has confirmed kaolinite preference for $\mathrm{K}$ over $\mathrm{Ca}^{2+}$

Ca-kaolinite $+2 \mathrm{~K}^{+}=\mathrm{Ca}^{2+}+2 \mathrm{~K}$-kaolinite

In the exchange system $\mathrm{Mg}-\mathrm{Ca}$ with kaolinite, the selectivity coefficient calculated from the isotherm adsorption (Udo, 1978) indicates low selectivity of $\mathrm{Mg}^{2+}$ compared to $\mathrm{Ca}^{2+}$.

In theory, the preference order of kaolinite $\left(\mathrm{K}^{+}>\mathrm{Ca}^{2+}>\mathrm{Mg}^{2+}>\mathrm{Na}^{+}\right)$and $\left(\mathrm{Ca}^{2+}>\mathrm{Mg}^{2+}>\mathrm{Na}^{+}>\right)$should explain the EC results and the hydrochemical evolution of the unsaturated zone solutions. The $\mathrm{pH}$ rise at mid depth of the profile may be explained primarily by progressive depletion of the exchangeable cations (Edmunds et al, 1992).

In the study, the sharp decrease in depth of $\mathrm{Ca} / \mathrm{Cl}$ and $\mathrm{K} /$ $\mathrm{Cl}$ molar ratios of the interstitial water could be the results of high selectivity of illite and kaolinite for these cations, which will obviously increase $\mathrm{Mg} / \mathrm{Cl}$ and $\mathrm{Na} / \mathrm{Cl}$ molar ratios in the same solutions.

At shallow depth (0 to $10 \mathrm{~m}$ ), molar ratios of cations in the unsaturated solutions are above those of rainwater reference. This increase seems to be controlled by hydrolysis reactions of the silicate minerals (mainly illite and to a lesser extend montmorillonite and feldspar).

The vertical profile of $\mathrm{Si} / \mathrm{Cl}$ confirms that weathering process is dominant at shallow depth. The calibrated $\mathrm{Si}$ / $\mathrm{Cl}$ molar ratio (Fig. 4d) indicates an increase in depths between 0 to $8 \mathrm{~m}$, and 13 to $26 \mathrm{~m}$. Quartz dissolution observed by SEM also contributes to this increase in Si. These processes occurring in the unsaturated zone have their signature in local groundwater. In fact, wells 26, 31 and 32 which are located near the profile L18 are characterised by sodium chloride facies (Fig. 2). 
(a)

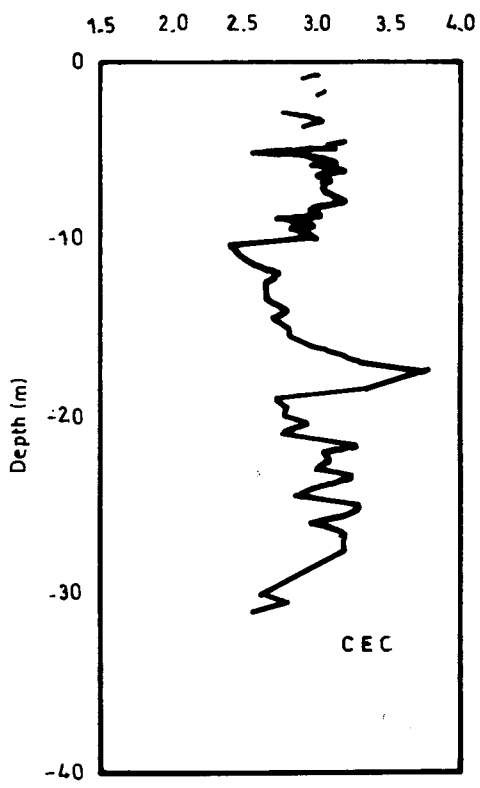

(c)

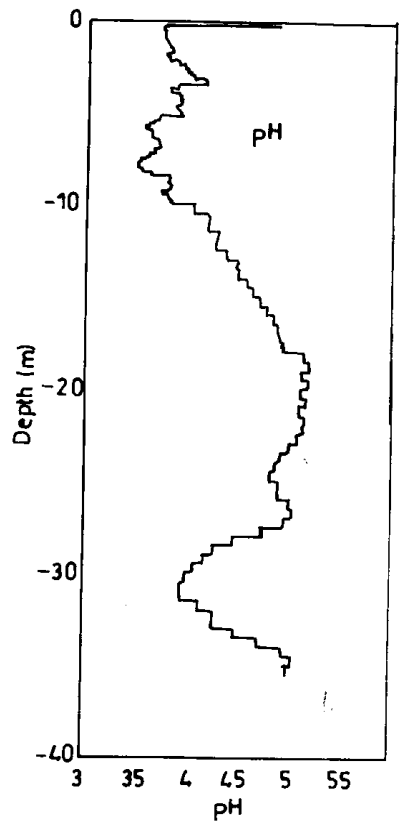

(b)

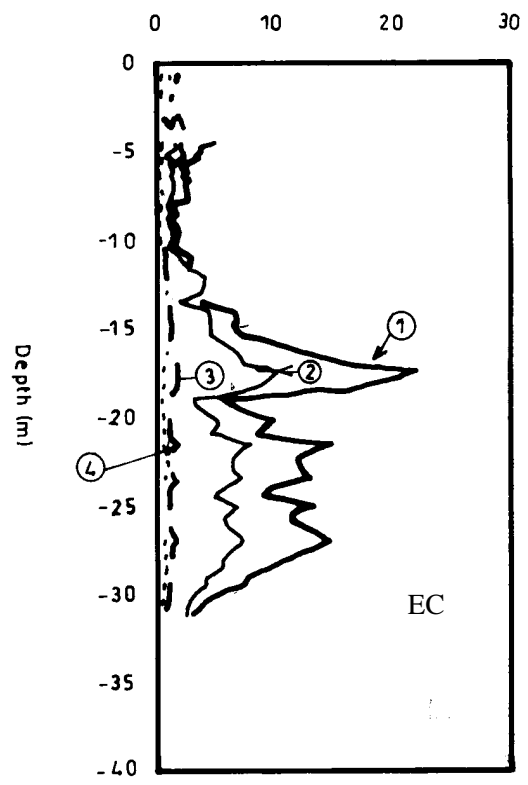

(d)

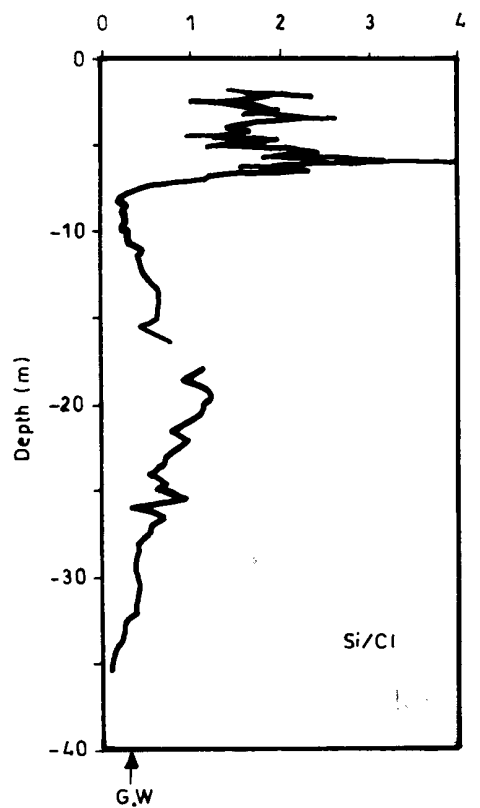

Figure 4. Vertical profile of CEC (4a), EC (4b) of the soil samples, the interstitial water $\mathrm{pH}(4 \mathrm{c})$ and $\mathrm{Si} / \mathrm{Cl}$ molar ratio (4d) $\left(1=\mathrm{Ca}^{2+} ; 2=\mathrm{Mg}^{2+} ; 3=\mathrm{K}^{+} ; 4=\mathrm{Na}^{+}\right)$

preference of the $\mathrm{Ca}^{2+}$ ion has been observed also by Dolcaster et al (1968) in montmorillonite samples. 


\section{CONCLUSION}

The vertical profile of the unsaturated zone solutions chemistry of Louga aquifer are controlled by silicates weathering processes at lower depth, followed by exchange reactions at the clay minerals surface. Long residence time of the solutions in the unsaturated zone media, which in the research site represents 74 years (Edmunds, 1990) record favours the contact between solutions and matrix and therefore water/rock interaction. Exchange reactions are the dominant processes, but selectivity reactions control the concentration of the cations. Preference of $\mathrm{Ca}^{2+}$ and $\mathrm{K}^{+}$over $\mathrm{Na}^{+}$and $\mathrm{Mg}^{2+}$ by the clay minerals explains the unsaturated zone solutions chemistry and also the local groundwater chemistry.

\section{REFERENCES}

Cook P.G., Edmunds, W.M. and Gaye, C.B. (1992). Estimating paleorecharge and paleoclimate from unsaturated zone profiles. Water Resources Research, no 28, pp 2721-2731.

Dolcater D. L., Lotse, E.G., Syers, J.K. and Jackson, M.L. (1968). Cation exchange selectivity of some clay sized minerals and soil materials. Soil Sciences Society American Proceeding. Volume 32, pp. 795798.

Edmunds W. M. (1990). Groundwater recharge in Senegal. Technical report WD/90/49 R-BGS, $150 \mathrm{p}$.

Edmunds W. M., Faye, S. and Gaye, C.B. (1992). Solute profiles in unsaturated quaternary sands from Senegal : Environmental information and water-rock interaction. Proceeding of the $7^{\text {th }}$ international Symposium on water-rock interaction. WRI-7/Park City/Utah/USA. Pp. 719-722.

Edmunds, W.M. and Gaye, C.B. (1994). Estimating the spatial variability of the groundwater recharge in the Sahel using chloride. Journal of Hydrology, no 156, pp. 47-59.

Faye. S. (1991). Geochemical processes occurring in the unsaturated zone of a quaternary sandstone aquifer (Louga-Senegal). Master of Sciences thesis. University of Leeds U.K., 103 p.
Faye. S. (1995). Modélisation hydrodynamique des nappes du Littoral Nord entre Cayar et St Louis. Impact des futurs prélèvements envisagés dans le cadre de l'approvisionnement en eau de Dakar et de ses environs. Thèse Doctorat Ingénieur, Université Cheikh Anta DIOP de Dakar, 166 p.

Faye S., Gaye, C.B., Faye, A. and Malou, R. (1997). Simulation of additional exploitation the littoral north aquifer system of Senegal in order to reduce water shortage in DAKAR. Proceedings of the XXVII ${ }^{\text {th }} I A H$ congress / Nottingham / United Kingdom / 21- 27 september 1997/.in Groundwater in urban Environment: Processes and Management, Chilton et al (eds) pp 315-318. (C) 1997 Balkema, ,Rotterdam, ISBN 9054108371.

Faye S., Gaye C.B. and Faye, A. (1998). Modelling the hydrodynamic behaviour of the north coast aquifer system of Senegal. Simulation of the additional extraction to reduce water shortage in Dakar. Hydrogeology BRGM no 1, pp. 13-22.

Gaye. C.B. and Edmunds, W.M. (1996). Groundwater recharge estimation using chloride, stable isotopes and tritium profiles in the sands of the north-western Senegal. Environmental Geology, no 27, pp. 246251.

Gillman P. G. (1970). A proposed method for the measurement of exchange site properties of highly weathered soils. Australian Journal of Soil Resources, no 17, pp. 15-24.

Goulding, K.W.T. and Talibudeen, D. (1980). Heterogeneity of the cation exchange sites for K-Ca exchange in alumino silicates. Journal of Colloids Interface Sciences, no 78, pp. 15-24.

Jensen H. E. (1973). K-Ca exchange equilibrium on montomorillonite and kaolinite clay, 1. A test on the Argersinger thermodynamic approach. Agrochemica no 17, pp. 181-189.

Kinniburgh D.G. and Miles, D.L. (1983). Extraction and chemical analysis of interstitial water from soils and rocks. Environmental Sciences Technology, no 17, pp. 362-368.

Udo E.J. (1978). Thermodynamics of K-Ca exchange reactions on a kaolinite soil clay. Soil Sciences Society American Journal no 42, pp. 556-560. 